\title{
Pengembangan Metode Uji Cepat Vigor Benih Kedelai dengan Pemunculan Radikula
}

\section{Development of Rapid Vigor Test Method for Soybean Seeds with Radicle Emergence}

\author{
Feny Astuti ${ }^{1}$, Candra Budiman ${ }^{2}$, dan Satriyas Ilyas ${ }^{2 *}$ \\ 'Program Studi Agronomi dan Hortikultura, Departemen Agronomi dan Hortikultura, Institut Pertanian Bogor \\ ${ }^{2}$ Departemen Agronomi dan Hortikultura, Fakultas Pertanian, Institut Pertanian Bogor \\ (IPB University), Jl. Meranti, Kampus IPB Darmaga, Bogor 16680, Indonesia
}

Diterima 13 Februari 2020/Disetujui 26 Juni 2020

\begin{abstract}
Seed vigor test to evaluate seed quality requires a faster, more precise, and simple method. Radicle emergence (RE) is a rapid vigor testing method that has been validated by International Rules for Seed Testing since 2014 on maize seeds. The objective of this research was to develop an RE method test as a rapid vigor test on soybean seeds. The experiments were conducted at the Seed Storage and Testing Laboratory, and Sawah Baru Experimental Station, IPB University, Bogor, from November 2018 to March 2019. The RE experiment was arranged in a randomized completely block design (RCBD) with repeated measurement in a split-plot design, using ten varieties as the main-plot and seven times of observation as the subplot. The RCBD with one factor (variety) were used for laboratory and field experiments. Determination of observation time for radicle emergence test was done from 36 through 48 hours after sowing with 2 hours interval. Results of the RE test were then correlated with other vigor tests, normal germination, and seedling vigor in the field. The results showed that the RE test on soybean seeds of ten varieties with different vigor levels (classified by vigor index) using top of paper germinating method at $25 \pm 2{ }^{\circ} \mathrm{C}$ and observed after 42 hours \pm 15 minutes was closely correlated and could predict the normal germination, vigor index, speed of germination, mean germination time, field emergence, and mean emergence time. Therefore, $R E$ can be used as a rapid vigor test for soybean seeds.
\end{abstract}

Keywords: field emergence, mean emergence time, mean germination time, normal germination percentage

\section{ABSTRAK}

Pengujian vigor untukmengevaluasi mutu benih memerlukan metode yang lebih cepat, tepat, dan mudah. Uji pemunculan radikula atau radicle emergence ( $R E$ ) merupakan metode pengujian vigor benih yang cepat dan telah divalidasi International Rules for Seed Testing sejak tahun 2014 pada benih jagung. Penelitian ini bertujuan untuk mengembangkan metode uji RE sebagai uji cepat vigor pada benih kedelai. Penelitian dilaksanakan di Laboratorium Penyimpanan dan Pengujian Mutu Benih serta Kebun Percobaan Sawah Baru IPB pada bulan November 2018 - Maret 2019. Rancangan kelompok lengkap teracak (RKLT) dengan pengamatan berulang pola split-plot digunakan pada percobaan uji RE, dengan sepuluh varietas sebagai petak utama dan tujuh waktu pengamatan sebagai anak petak. Rancangan percobaan RKLT dengan satu faktor yaitu varietas digunakan untuk pengujian vigor benih dan daya berkecambah di laboratorium, dan vigor bibit di lapangan. Penentuan waktu pengamatan RE yang tepat dilakukan dengan interval 2 jam mulai dari 36 jam setelah pengecambahan (JSP) hingga 48 JSP. Hasil uji RE dikorelasikan dengan hasil uji beberapa tolok ukur vigor lainnya, daya berkecambah, dan vigor bibit di lapangan. Hasil penelitian menunjukkan bahwa uji RE pada benih kedelai dari sepuluh varietas yang berbeda tingkat vigor (pemilahan berdasarkan nilai indeks vigor) dengan metode uji diatas kertas pada suhu $25 \pm 2{ }^{\circ} \mathrm{C}$ dan diamati pada 42 jam \pm 15 menit setelah pengecambahan berkorelasi erat dan dapat memprediksi daya berkecambah, indeks vigor, kecepatan tumbuh, rataan waktu perkecambahan, daya tumbuh di lapangan, dan rataan waktu pemunculan bibit. Oleh karena itu, RE dapat digunakan sebagai uji cepat vigor benih kedelai.

Kata kunci: daya berkecambah, daya tumbuh, rataan waktu perkecambahan, rataan waktu pemunculan bibit

\footnotetext{
* Penulis untuk korespondensi. e-mail: satriyas252@gmail.com
} 


\section{PENDAHULUAN}

Program sertifikasi benih pada tahap pengujian benih membutuhkan waktu relatif lama, sedangkan umur simpan benih kedelai relatif singkat. Menurut Hipi et al. (2016), benih kedelai cepat mengalami deteriorasi dalam waktu 3 bulan untuk kedelai biji besar dan 5 bulan untuk kedelai biji kecil. Berdasarkan Kepmentan (2018), masa edar benih kedelai bersertifikat menjadi 4 (empat) bulan setelah selesai pengujian. Masa simpan benih yang pendek pada benih kedelai sering menjadi kendala dalam sertifikasi benih. Untuk itu, perlu pengembangan metode pengujian yang dapat memberikan hasil dalam waktu singkat. Uji cepat vigor pada kedelai yang pernah dilakukan sebelumnya yaitu uji tetrazolium. Dina et al. (2007) menyatakan apabila pewarnaan pada kotiledon terbentuk merata dan poros embrio berwarna merah atau tanpa merah tua di ujung radikula dikategorikan sebagai pola vigor karena berhubungan erat dengan daya tumbuh. Menurut Mavi et al. (2016), uji RE dan uji konduktivitas listrik dapat digunakan dalam memprediksi kecambah normal benih lobak (Raphanus sativus L.).

Uji pemunculan radikula atau radicle emergence (RE) merupakan metode pengujian vigor cepat yang telah divalidasi untuk benih jagung pada suhu $20{ }^{\circ} \mathrm{C}$ setelah benih dikecambahkan 66 jam \pm 15 menit atau pada suhu $13{ }^{\circ} \mathrm{C}$ setelah 144 jam \pm 1 jam (ISTA, 2017); benih lobak (Raphanus sativus L.) pada suhu $20{ }^{\circ} \mathrm{C}$ setelah 48 jam (Matthews et al., 2011); oilseed rape (Brassica napus L.) pada suhu $20{ }^{\circ} \mathrm{C}$ setelah 30 jam (Powell dan Mavi, 2016); dan terong (Solanum melongena L.) pada suhu konstan $20{ }^{\circ} \mathrm{C}$ atau suhu berganti $20^{\circ} \mathrm{C}$ selama 16 jam dan suhu $30^{\circ} \mathrm{C}$ selama 8 jam, setelah benih dikecambahkan 104 jam (Ozden et al., 2018). Evaluasi hasil pengujian dilakukan lebih awal yaitu ketika radikula telah muncul minimal sepanjang $2 \mathrm{~mm}$, sehingga uji RE dikatakan lebih cepat dibandingkan uji vigor lainnya. Prinsip metode uji RE adalah benih yang berkecambah lambat merupakan tanda awal kemunduran fisiologis benih dan menunjukkan bahwa lot benih tersebut bervigor rendah (ISTA, 2017).

Walaupun metode uji RE telah diteliti pada berbagai spesies (Mathews dan Powell, 2011), tetapi belum pernah dilaporkan pada benih kedelai. Oleh karena itu, penelitian ini dilakukan untuk mengembangkan metode uji RE sebagai uji cepat vigor benih kedelai melalui 1) penentuan waktu pemunculan radikula yang tepat, dan 2) mengkorelasikan hasil uji RE dengan hasil uji beberapa tolok ukur vigor lainnya.

\section{BAHAN DAN METODE}

Penelitian dilaksanakan pada bulan November 2018 sampai Maret 2019 di Laboratorium Penyimpanan dan Pengujian Mutu Benih dan Kebun Percobaan Sawah Baru, IPB. Bahan yang digunakan adalah 10 varietas benih kedelai yaitu Agromulyo, Dena 1, Deja 1, Detap 1, Devon 1, Devon 2, Demas 1, Gepak kuning, Anjasmoro, dan Grobogan yang diperoleh dari Balai Penelitian Tanaman Aneka Kacang dan
Umbi (Balitkabi), Malang, Jawa Timur. Pengujian awal yang dilakukan terhadap sampel benih yaitu pengujian kadar air (KA) menggunakan suhu rendah konstan $103{ }^{\circ} \mathrm{C}$ selama $17 \pm 1$ jam dengan dua ulangan masing-masing sampel 5 gram.

Pengujian radicle emergence (RE) di laboratorium disusun menggunakan rancangan kelompok lengkap teracak (RKLT) dengan pengamatan berulang berpola split-plot (sepuluh varietas sebagai petak utama dan tujuh waktu pengamatan sebagai anak petak) dengan 4 ulangan (50 butir benih per ulangan). Kecambah dihitung jika panjang radikula yang tumbuh minimum $2 \mathrm{~mm}$ (ISTA, 2017). Pengujian RE menggunakan metode uji diatas kertas (UDK) dalam cawan petri dengan media tanam tiga lembar kertas buram, dikecambahkan dalam germinator standar bersuhu $25 \pm 2{ }^{\circ} \mathrm{C}$. Sebelum waktu pengecambahan 36 jam, dilakukan penyemprotan akuades sebanyak $\pm 5 \mathrm{ml}$ per cawan petri setiap 12 jam. Setelah waktu pengecambahan 36 jam, cawan petri juga disemprot akuades setiap pengamatan. Pengujian mean germination time (MGT) juga dilakukan untuk menentukan rataan waktu perkecambahan benih.

Pengujian mutu benih di laboratorium yatu daya berkecambah (DB), indeks vigor (IV), dan kecepatan tumbuh $\left(\mathrm{K}_{\mathrm{CT}}\right)$ disusun secara RKLT satu faktor yaitu varietas sebanyak 4 ulangan (50 butir benih per ulangan). Pengujian DB, IV, dan $\mathrm{K}_{\mathrm{CT}}$ dilakukan dengan metode uji kertas digulung dengan plastik (UKDdp) pada germinator standar suhu $25 \pm 2{ }^{\circ} \mathrm{C}$. Pengujian DB dihitung berdasarkan persentase total kecambah normal pada hari hitung pertama (5 hari) dan hitungan terakhir (8 hari). Pengujian IV dihitung berdasarkan persentase kecambah normal pada hari hitung pertama (5 hari). Pengujian $\mathrm{K}_{\mathrm{CT}}$ dihitung berdasarkan persentase pertambahan kecambah normal per etmal (24 jam) hingga hitungan terakhir ( 8 hari). Kecambah dinyatakan tumbuh normal jika panjang plumula dan radikula benih minimal 4 kali panjang benih, dengan pertumbuhan yang proporsional. Pengujian mutu benih di lapangan untuk menguji mean emergence time (MET) dan daya tumbuh (DT) hingga 8 hari setelah tanam (HST). Pengujian MET dihitung berdasarkan rataan waktu pemunculan poros kecambah ke atas permukaan tanah hingga 8 HST. Pengujian DT dihitung berdasarkan persentase kecambah yang tumbuh di lapangan pada 8 HST. Rancangan percobaan yang digunakan yaitu RKLT satu faktor varietas sebanyak 4 ulangan (50 butir benih per ulangan). Pengujian di lapangan dilakukan dengan menanam sepuluh varietas benih kedelai dengan kedalaman 2-3 $\mathrm{cm}$ pada bedengan berukuran $1 \mathrm{~m} \mathrm{x} 1 \mathrm{~m}$ dan tinggi bedengan $15 \mathrm{~cm}$ dengan jarak tanam $20 \mathrm{~cm}$ x $10 \mathrm{~cm}$.

\section{HASIL DAN PEMBAHASAN}

\section{Pengujian Mutu Benih Kedelai di Laboratorium dan Lapangan}

Pengujian mutu benih kedelai di laboratorium menunjukkan hasil yang berbeda nyata pada seluruh varietas dengan tolok ukur $\mathrm{KA}, \mathrm{IV}, \mathrm{K}_{\mathrm{CT}}$, dan MGT tetapi tidak berbeda nyata pada tolok ukur DB berdasarkan 
hasil uji F (Tabel 1). Sepuluh varietas benih kedelai yang diuji merupakan kelas benih Foundation Seed (FS) dan berumur empat bulan ketika digunakan untuk pengujian di laboratorium. Berdasarkan Kepmentan (2018), DB minimal untuk kelas Benih Dasar kedelai adalah 80\% dengan kadar air maksimal 11\%. Nilai DB tidak berbeda nyata yaitu berkisar 86-94\% dengan kadar air 7.3-9.6\%, sehingga benih memiliki viabilitas yang sama ketika digunakan.

Vigor benih merupakan konsep yang mencerminkan beberapa karakter penentu mutu benih dan potensi keseragaman tanaman di lapangan dengan rentang variabel lingkungan yang luas (Finch-Savage and Bassel, 2016). Hasil uji $\mathrm{F}$ pada tolok ukur IV menunjukkan nilai tertinggi pada varietas Gepak kuning yaitu $81 \%$, tidak berbeda nyata dengan varietas Agromulyo, Deja 1, dan Demas 1 (IV=63$76 \%$ ). Nilai IV keempat varietas tersebut berbanding terbalik dengan nilai MGT, artinya perkecambahan benih keempat varietas tersebut lebih cepat dan dapat dikategorikan sebagai lot vigor tinggi (Tabel 1). Nilai MGT meningkat pada lot benih yang telah mengalami deteriorasi (Demir et al., 2008; Matthews dan Powell, 2011).

Mean germination time (MGT) atau rataan waktu perkecambahan adalah waktu yang dibutuhkan untuk berkecambah mulai dari imbibisi hingga pemunculan radikula (Matthews dan Khajeh-Hosseini, 2006). Lot benih dengan MGT rendah berkecambah lebih cepat dan memiliki persentase akhir daya berkecambah yang tinggi (Matthews dan Powell, 2011). Hasil uji F menunjukkan bahwa nilai MGT yang rendah memiliki nilai $\mathrm{DB}$, IV, serta $\mathrm{K}_{\mathrm{CT}}$ yang tinggi seperti pada varietas Agromulyo, Deja 1, Demas 1, dan Gepak kuning dengan MGT berkisar 36.00-36.39 jam (Tabel 1).

Nilai $\mathrm{K}_{\mathrm{CT}}$ pada varietas Demas 1 dan Gepak kuning lebih tinggi dibandingkan varietas lainnya yaitu $26.9 \%$ dan tidak berbeda nyata dengan varietas Agromulyo dan Deja 1 yaitu 25.8-25.9\%. Nilai $\mathrm{K}_{\mathrm{CT}}$ sebanding dengan nilai IV (Tabel 1). Menurut Sadjad et al. (1999), benih vigor menunjukkan nilai $\mathrm{K}_{\mathrm{CT}}$ yang tinggi karena benih berkecambah cepat pada waktu yang relatif lebih singkat, sedangkan benih kurang vigor memerlukan waktu lebih lama untuk berkecambah.

Tabel 2 menunjukkan hasil pengujian mutu benih kedelai di lapangan. Benih berumur tujuh bulan untuk pengujian di lapangan. Berdasarkan uji DB, seluruh benih masih memiliki viabiltas yang baik dengan nilai DB berkisar 86-94\%. Daya tumbuh (DT) benih kedelai di lapangan yang paling rendah adalah $66.5 \%$ pada varietas Grobogan tetapi tidak berbeda nyata dengan benih bervigor sedang lainnya (DT $=69.5-81.5 \%$ ). Daya tumbuh benih bervigor tinggi berkisar antara $82.0-89.5 \%$. Terjadi peningkatan nilai DT dengan penurunan nilai MET. Mean emergence time (MET) atau rataan waktu pemunculan bibit adalah waktu yang dibutuhkan untuk tumbuh mulai dari imbibisi hingga munculnya poros kecambah di permukaan tanah (Matthews dan Khajeh-Hosseini, 2006). Nilai MET yang paling rendah yaitu pada Gepak kuning (4.85 hari) dan tidak berbeda nyata dengan varietas Agromulyo, Deja 1, dan Demas 1 berkisar antara 4.90-5.48 hari. Nilai MET sebanding dengan nilai MGT di laboratorium (Tabel 1). Penelitian ini sesuai dengan Matthews dan Khajeh-Hosseini (2006) yaitu nilai MET berkorelasi positif dengan MGT, dan MGT berpotensi sebagai indikator DT pada benih jagung.

Tabel 1. Hasil pengujian mutu benih kedelai di laboratorium

\begin{tabular}{|c|c|c|c|c|c|}
\hline $\begin{array}{l}\text { Kode } \\
\text { varietas }\end{array}$ & $\mathrm{KA}(\%)$ & DB $(\%)$ & IV $(\%)$ & $\mathrm{KCT}\left(\%\right.$. etmal $\left.^{-1}\right)$ & MGT (jam) \\
\hline V1 & $8.2 \mathrm{~cd}$ & 91 & $67 a b c$ & $25.9 \mathrm{ab}$ & $36.22 b c$ \\
\hline $\mathrm{V} 3$ & $8.3 \mathrm{~cd}$ & 88 & $63 a b c$ & $25.8 \mathrm{abc}$ & $36.39 \mathrm{bc}$ \\
\hline V7 & $9.3 \mathrm{ab}$ & 94 & $76 \mathrm{ab}$ & $26.9 \mathrm{a}$ & $36.39 b c$ \\
\hline V8 & $8.8 \mathrm{bc}$ & 93 & $81 \mathrm{a}$ & $26.9 a$ & $36.00 \mathrm{c}$ \\
\hline $\mathrm{V} 2$ & $8.5 \mathrm{~cd}$ & 91 & $50 \mathrm{~cd}$ & $23.6 \mathrm{~cd}$ & $37.85 \mathrm{a}$ \\
\hline V4 & $8.5 \mathrm{~cd}$ & 89 & $53 \mathrm{~cd}$ & $23.7 \mathrm{bcd}$ & $37.63 \mathrm{a}$ \\
\hline V5 & $9.6 \mathrm{a}$ & 92 & $60 \mathrm{bcd}$ & $24.4 \mathrm{bcd}$ & $37.27 \mathrm{ab}$ \\
\hline V6 & $7.3 \mathrm{e}$ & 91 & $59 \mathrm{bcd}$ & $24.3 \mathrm{bcd}$ & $37.58 \mathrm{a}$ \\
\hline V9 & $8.0 \mathrm{de}$ & 87 & $52 \mathrm{~cd}$ & $23.6 \mathrm{bcd}$ & $37.82 \mathrm{a}$ \\
\hline V10 & $7.5 \mathrm{e}$ & 86 & $42 d$ & $23.2 \mathrm{~d}$ & $38.29 \mathrm{a}$ \\
\hline $\operatorname{Pr}(>F)$ & $* *$ & $\operatorname{tn}$ & $* *$ & $* *$ & $* *$ \\
\hline KK (\%) & 3.43 & 5.53 & 19.43 & 5.53 & 1.90 \\
\hline
\end{tabular}

Keterangan: Benih kedelai dari sepuluh varietas dipanen pada Juli 2018 dan kadaluarsa pada Maret 2019 (sumber: Balitkabi). Pengujian benih dilakukan pada 7 November - 7 Desember 2018. Angka-angka yang diikuti huruf yang sama pada kolom yang sama tidak berbeda nyata berdasarkan uji DMRT pada $\alpha=5 \%$; ** = berpengaruh nyata pada $\alpha=1 \%$; tn = tidak berpengaruh nyata; $\mathrm{KA}=$ kadar air; $\mathrm{DB}=$ daya berkecambah UKDdp; IV = indeks vigor; KCT = kecepatan tumbuh; MGT = mean germination time $; \mathrm{KK}=$ koefisien keragaman; V1 = Agromulyo; V2 = Dena 1; V3 = Deja 1; V4 = Detap 1; V5 = Devon 1; V6 = Devon 2; $\mathrm{V} 7=$ Demas $1 ; \mathrm{V} 8=$ Gepak kuning; V9 = Anjasmoro; V10 = Grobogan 
Tabel 2. Hasil pengujian mutu benih kedelai di lapangan

\begin{tabular}{lcc}
\hline Kode varietas & DT 8 HST (\%) & MET (hari) \\
\hline V1 & $89.5 \mathrm{a}$ & $4.94 \mathrm{~cd}$ \\
V3 & $84.0 \mathrm{abc}$ & $5.48 \mathrm{abcd}$ \\
V7 & $86.0 \mathrm{a}$ & $4.90 \mathrm{~cd}$ \\
V8 & $82.0 \mathrm{abc}$ & $4.85 \mathrm{~d}$ \\
V2 & $76.0 \mathrm{abc}$ & $5.99 \mathrm{ab}$ \\
V4 & $81.0 \mathrm{abc}$ & $5.49 \mathrm{abc}$ \\
V5 & $81.5 \mathrm{abc}$ & $5.79 \mathrm{ab}$ \\
V6 & $77.0 \mathrm{abc}$ & $5.37 \mathrm{bcd}$ \\
V9 & $69.5 \mathrm{bc}$ & $5.90 \mathrm{ab}$ \\
V10 & $66.5 \mathrm{c}$ & $6.07 \mathrm{a}$ \\
\hline Pr $(>$ F $)$ & tn & $* *$ \\
\hline KK $(\%)$ & 13.37 & 7.16 \\
\hline
\end{tabular}

Keterangan: Sepuluh varietas benih dipanen pada Juli 2018 dan kadaluarsa pada Maret 2019. Pengujian benih dilakukan pada 1 Februari 2019 - 8 Maret 2019. Angka-angka yang diikuti huruf yang sama pada kolom yang sama tidak berbeda nyata berdasarkan uji DMRT pada $\alpha=5 \%$; ** = berpengaruh nyata pada $\alpha=1 \%$; tn $=$ tidak berpengaruh nyata; DT 8 HST $=$ daya tumbuh 8 hari setelah tanam; MET $=$ mean emergence time; $\mathrm{KK}=$ koefisien keragaman; $\mathrm{V} 1=$ Agromulyo; V2 = Dena 1; V3 = Deja 1; V4 = Detap $1 ; \mathrm{V} 5=$ Devon 1; V6 = Devon 2; V7 = Demas 1; V8 = Gepak kuning; V9 = Anjasmoro; V10 = Grobogan

\section{Penentuan Waktu Pengamatan Uji RE}

Penentuan waktu pengamatan RE dilakukan berdasarkan nilai korelasi (r) dan koefisien determinasi $\left(\mathrm{R}^{2}\right)$ tertinggi antara nilai DB dan nilai RE (Tabel 3). Korelasi nyata dan cukup erat antara RE dan DB terjadi pada periode pengecambahan 42 jam dengan nilai $\mathrm{R}^{2}=0.57$ dan $\mathrm{r}=0.78$. Apabila pada persamaan garis $\mathrm{y}=0.33 \mathrm{x}+59.59$ dimasukkan nilai $\mathrm{RE}=80 \%$, maka diperoleh nilai $\mathrm{DB}=85.9 \%$. Ozden et al. (2018) menentukan waktu pengamatan RE berdasarkan nilai koefisien determinasi $\left(\mathrm{R}^{2}\right)$ tertinggi dari regresi linier antara RE dan DB pada benih terong. Menurut KhajehHosseini et al. (2010), penghitungan RE setelah 48 jam pengecambahan berkorelasi nyata dengan jumlah kecambah normal pada benih oilseed rape.

Penentuan waktu RE juga dilakukan berdasarkan kenaikan persentase pertambahan nilai RE (Tabel 4). Varietas Agromulyo, Deja 1, Demas 1, dan Gepak Kuning sudah menunjukkan persentase RE maksimum pada periode pengecambahan $36 \mathrm{jam}$. Keempat varietas tersebut dikategorikan sebagai lot bervigor tinggi (nilai IV 63-81\% pada Tabel 1), karena perkecambahan lebih cepat. Varietas Devon 1, Dena 1, Detap 1, Devon 2, dan Anjasmoro menunjukkan persentase RE maksimum pada periode pengecambahan 42 jam sebagai lot bervigor sedang (nilai $\mathrm{IV}=50-60 \%$ pada Tabel 1). Oleh karena varietas Grobogan menunjukkan kenaikan persentase RE maksimum paling lambat (46 jam), maka dikategorikan sebagai lot bervigor rendah (nilai IV $=42 \%$ pada Tabel 1 ).

Waktu pengamatan RE juga ditentukan dengan melihat kenaikan grafik pertambahan RE pada jam pengamatan tertentu (Gambar 1). Lot vigor tinggi sudah terjadi kenaikan RE pada jam ke-36, sedangkan lot vigor sedang terjadi kenaikan pada jam ke-42. Setelah jam ke-42, semua varietas tidak mengalami peningkatan secara nyata kecuali lot vigor rendah (Grobogan). Oleh karena itu, penentuan waktu pengamatan RE untuk benih kedelai yang direkomendasikan adalah 42 jam. Berdasarkan hal tersebut maka dilakukan analisis regresi dan korelasi dengan beberapa tolok ukur vigor pada waktu pengamatan 42 jam.

\section{Analisis Regresi dan Korelasi}

Gambar 2A menunjukkan korelasi yang sangat erat dan hubungan linier yang negatif antara RE dengan MGT. Sebesar $80 \%\left(\mathrm{R}^{2}=0.80\right)$ keragaman MGT dapat dijelaskan oleh persamaan $\mathrm{y}=-0.12 \mathrm{x}+48.46$. Ini sesuai dengan Matthews et al. (2018), nilai RE berkorelasi erat dengan MGT serta dapat memprediksi DB pada benih oilseed rape. Gambar 2B menunjukkan korelasi yang erat dan hubungan linier positif antara RE pada jam ke-42 dengan DB. Nilai $\mathrm{R}^{2}$ sebesar 0.57 menunjukkan bahwa $57 \%$ nilai $\mathrm{DB}$ dapat dijelaskan oleh persamaan regresi linier $y=0.33 x+59.59$.

Tabel 3. Hubungan linier antara nilai RE dengan DB pada beberapa periode pengecambahan

\begin{tabular}{lccl}
\hline $\begin{array}{l}\text { Periode pengecambahan } \\
(\text { jam }) \pm 15 \text { menit }\end{array}$ & $\mathrm{R}^{2}$ & $\mathrm{r}$ & Persamaan garis \\
\hline 36 & 0.44 & $0.67^{*}$ & $\mathrm{y}=0.0960 \mathrm{x}+82.993$ \\
38 & 0.38 & $0.61 \mathrm{tn}$ & $\mathrm{y}=0.1230 \mathrm{x}+80.069$ \\
40 & 0.40 & $0.63^{*}$ & $\mathrm{y}=0.2002 \mathrm{x}+72.416$ \\
42 & 0.57 & $0.78^{*}$ & $\mathrm{y}=0.3293 \mathrm{x}+59.591$ \\
44 & 0.47 & $0.68^{*}$ & $\mathrm{y}=0.4148 \mathrm{x}+50.507$ \\
46 & 0.42 & $0.65^{*}$ & $\mathrm{y}=0.5836 \mathrm{x}+33.855$ \\
48 & 0.50 & $0.71^{*}$ & $\mathrm{y}=0.8213 \mathrm{x}+10.247$ \\
\hline
\end{tabular}

Keterangan: $\mathrm{x}=$ nilai $\mathrm{RE} ; \mathrm{y}=$ nilai $\mathrm{DB} ; \mathrm{R}^{2}=$ koefisien determinasi; $\mathrm{r}=$ koefisien korelasi; * = berbeda nyata pada taraf $\alpha=5 \%$; $\mathrm{tn}=$ tidak nyata 
Tabel 4. Persentase RE masing-masing varietas pada setiap waktu pengamatan

\begin{tabular}{|c|c|c|c|c|c|c|c|}
\hline \multirow{2}{*}{$\begin{array}{l}\text { Kode } \\
\text { Varietas }\end{array}$} & \multicolumn{7}{|c|}{ Waktu pengecambahan (jam) } \\
\hline & 36 & 38 & 40 & 42 & 44 & 46 & 48 \\
\hline V1 & 93.0Aa & $96.0 \mathrm{Aa}$ & $97.0 \mathrm{Aa}$ & 99.0Aa & 99.0Aa & 99.0Aa & $99.0 \mathrm{Aa}$ \\
\hline V3 & $88.5 \mathrm{Ab}$ & $92.5 \mathrm{Aab}$ & $96.5 \mathrm{Aa}$ & $96.5 \mathrm{Aa}$ & $97.5 \mathrm{Aa}$ & $97.5 \mathrm{Aa}$ & 98.0Aa \\
\hline V7 & $98.5 \mathrm{Aa}$ & $99.5 \mathrm{Aa}$ & $99.5 \mathrm{Aa}$ & $99.5 \mathrm{Aa}$ & $99.5 \mathrm{Aa}$ & $99.5 \mathrm{Aa}$ & $99.5 \mathrm{Aa}$ \\
\hline V8 & $98.5 \mathrm{Aa}$ & $98.5 \mathrm{Aa}$ & $98.5 \mathrm{Aa}$ & $98.5 \mathrm{Aa}$ & $98.5 \mathrm{Aa}$ & $98.5 \mathrm{Aa}$ & 98.5Aa \\
\hline $\mathrm{V} 2$ & $58.0 \mathrm{CDd}$ & $72.5 \mathrm{BCc}$ & $82.5 \mathrm{Bb}$ & $92.0 \mathrm{Aa}$ & $98.5 \mathrm{Aa}$ & $98.5 \mathrm{Aa}$ & 99.0Aa \\
\hline V4 & $64.5 \mathrm{BCd}$ & $73.5 \mathrm{BCc}$ & $82.0 \mathrm{Bb}$ & 88.0Abab & $91.5 \mathrm{Aba}$ & $93.0 \mathrm{Aa}$ & $95.0 \mathrm{Aa}$ \\
\hline V5 & $73.5 \mathrm{Bc}$ & $80.0 \mathrm{Bbc}$ & $86.5 \mathrm{Bb}$ & $93.5 \mathrm{Aa}$ & 95.0Aba & $95.0 \mathrm{Aa}$ & $97.5 \mathrm{Aa}$ \\
\hline V6 & $66.0 \mathrm{BCc}$ & $71.5 \mathrm{BCc}$ & $86.0 \mathrm{Bb}$ & $92.5 \mathrm{Aab}$ & 96.0Aba & $97.0 \mathrm{Aa}$ & $97.5 \mathrm{Aa}$ \\
\hline V9 & $59.0 \mathrm{Cde}$ & $75.5 \mathrm{Bd}$ & $83.5 \mathrm{Bc}$ & $90.0 \mathrm{ABbc}$ & 96.0Abab & $97.0 \mathrm{Aa}$ & $97.5 \mathrm{Aa}$ \\
\hline V10 & $51.0 \mathrm{De}$ & $64.0 \mathrm{Cd}$ & $76.5 \mathrm{Bc}$ & $80.0 \mathrm{Bbc}$ & 85.5Bab & $90.5 \mathrm{Aa}$ & $92.0 \mathrm{Aa}$ \\
\hline
\end{tabular}

Keterangan: Angka-angka yang diikuti huruf kapital pada baris yang sama atau huruf kecil pada kolom yang sama tidak berbeda nyata berdasarkan uji DMRT taraf $\alpha=5 \%$; 1 = Agromulyo; V2 = Dena 1; V3 = Deja 1; V4 = Detap 1; V5 = Devon 1; V6= Devon 2; V7 = Demas 1; V8 = Gepak kuning; V9 = Anjasmoro; V10 = Grobogan

Studi pada benih padi juga menunjukkan korelasi antara RE dan DB (Onwimol et al., 2016). Gambar 2C menunjukkan korelasi yang sangat erat dan hubungan linier yang positif antara RE dengan IV. Nilai $\mathrm{R}^{2}$ sebesar 0.79 menunjukkan bahwa $79 \%$ nilai IV dapat dijelaskan oleh persamaan regresi linier $\mathrm{y}=1.77 \mathrm{x}-104.22$. Gambar 2D menunjukkan korelasi yang sangat erat dan hubungan linier yang positif sangat nyata antara $\mathrm{RE}$ dan $\mathrm{K}_{\mathrm{CT}}$. Sebesar $74 \%\left(\mathrm{R}^{2}=0.74\right)$ keragaman $\mathrm{K}_{\mathrm{CT}}$ dapat dijelaskan oleh persamaan regresi linier $\mathrm{y}=0.20 \mathrm{x}+5.93$.

Korelasi antara RE dan vigor bibit di lapangan ditunjukkan pada Gambar 3. Nilai DT sebesar 72\% dapat dijelaskan oleh RE dengan persamaan garis linier $\mathrm{y}=1.01 \mathrm{x}-$ 14.7 (Gambar 3A). Apabila dimasukkan nilai $\mathrm{RE}=80 \%$, maka DT $=66.2 \%$. Hasil analisis berkorelasi erat $(r=0.85)$ dan hubungan linier positif yang sangat nyata dengan DT.
Hal ini sesuai dengan penelitian Ermis et al. (2015) yang menyatakan bahwa RE dapat memprediksi daya tumbuh benih bawang prei (Allium porrum) pada growing cabinet yang terkontrol. Demir et al. (2019) juga membuktikan bahwa persentase RE setelah 24 jam dapat digunakan untuk memperkirakan potensi munculnya bibit Lepidium sativum di lapangan.

Gambar 3B menunjukan adanya korelasi yang erat dan hubungan linier yang negatif antara RE dan MET sebesar 0.79. Keragaman nilai MET sebesar $63 \%$ dapat dijelaskan oleh RE dengan garis persamaan linier $\mathrm{y}=-0.06 \mathrm{x}+11.12$. Hal ini sesuai dengan hasil penelitian terdahulu yaitu nilai RE pada benih Elymus nutans berkorelasi erat dengan MET di lapangan (Lv et al., 2016), demikian pula pada benih jagung (Matthews dan Khajeh-Hosseini, 2006).

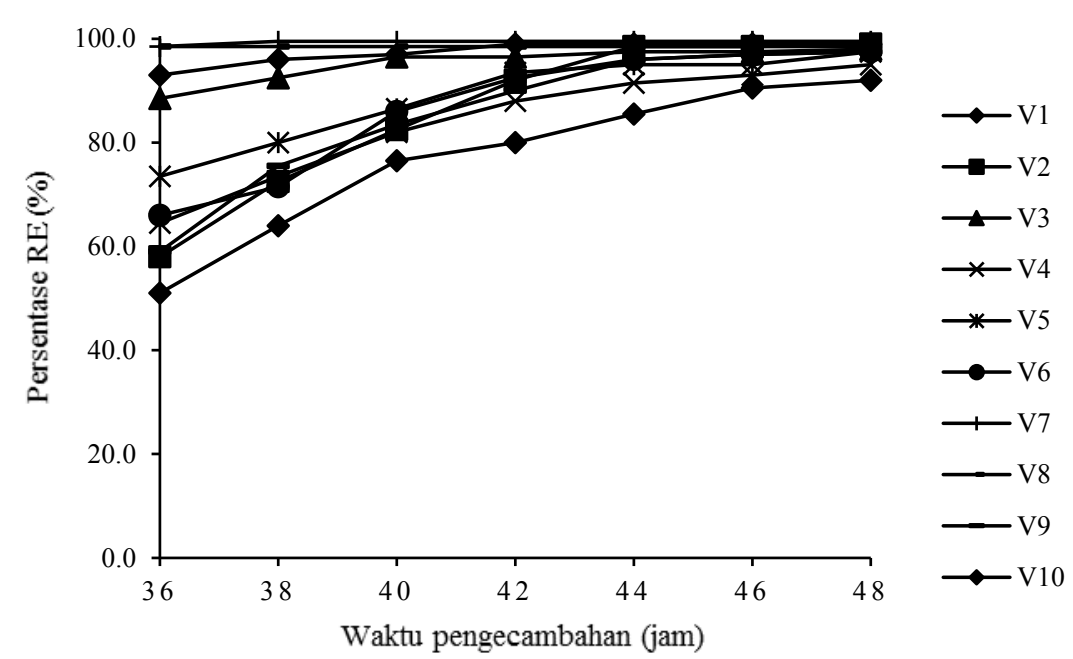

Gambar 1. Persentase RE pada sepuluh varietas benih kedelai mulai dari jam ke-36 sampai jam ke-48 setelah pengecambahan pada setiap selang 2 jam, V1 = Agromulyo; V2 = Dena 1; V3 = Deja 1; V4 = Detap 1; V5 = Devon 1; V6 = Devon 2; V7 = Demas 1; V8 = Gepak kuning; V9 = Anjasmoro; V10 = Grobogan 
A

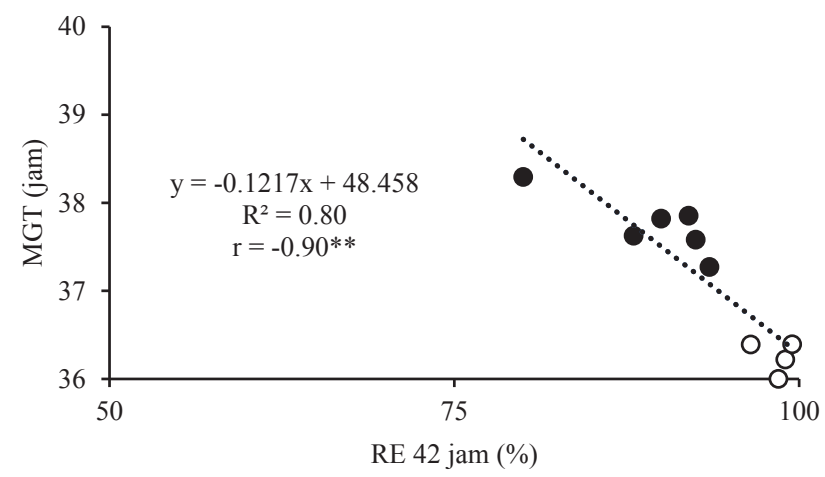

$\mathrm{C}$

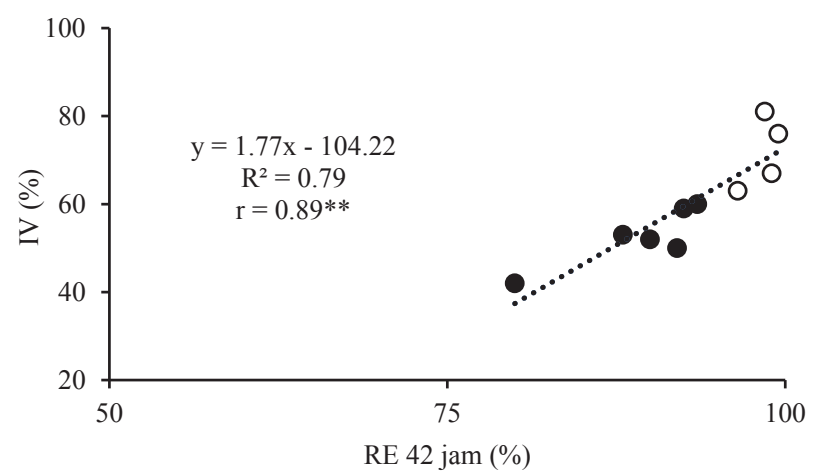

lot benih bermutu sedang - rendah (V2, V4, V5, V6, V9, V10)
B

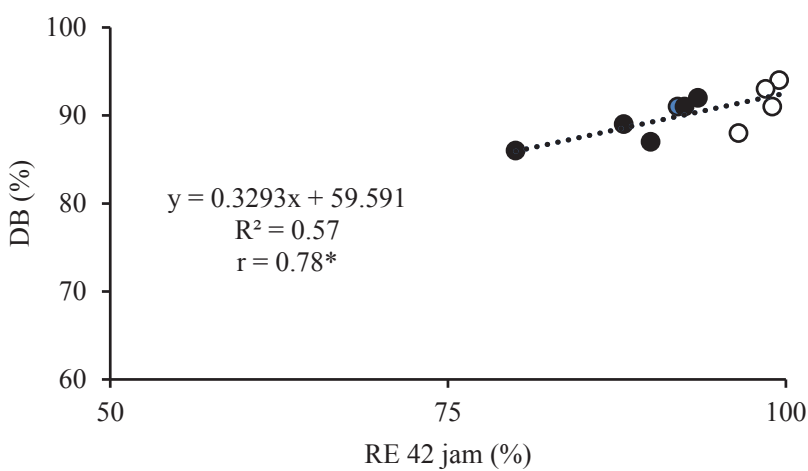

$\mathrm{D}$

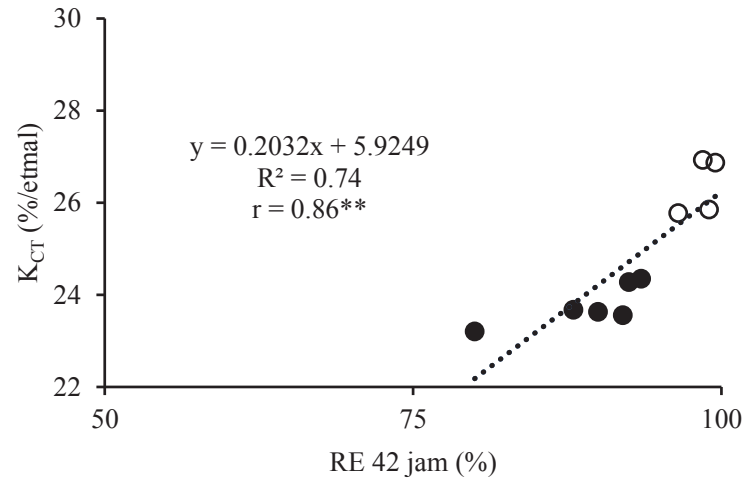

$\mathrm{O}:$ lot benih bermutu tinggi (V1, V3, V7, V8)

Gambar 2. Korelasi antara RE pada periode pengecambahan 42 jam dengan mean germination time (A), daya berkecambah (B), indeks vigor (C), kecepatan tumbuh (D) pada sepuluh varietas benih kedelai, **: berbeda nyata pada taraf $\alpha=1 \%$, *: berbeda nyata pada taraf $\alpha=5 \%$

A

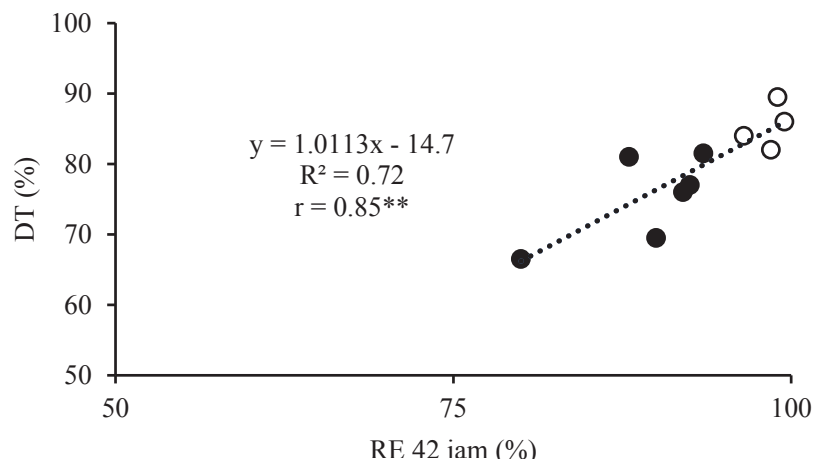

lot benih bermutu sedang-rendah (V2, V4, V5, V6, V9, V10)
B

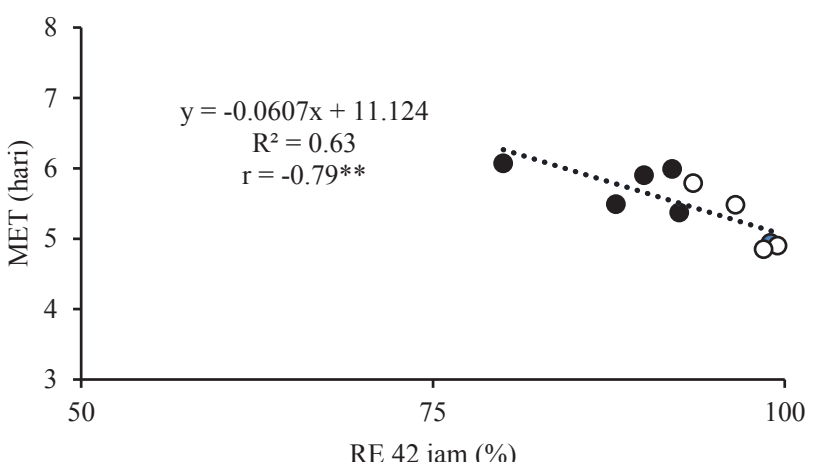

O: lot benih bermutu tinggi (V1, V3, V7, V8)

Gambar 3. Korelasi antara RE pada periode pengecambahan 42 jam dengan daya tumbuh (A), mean emergence time (B) pada sepuluh varietas benih kedelai, **: berbeda nyata pada $\alpha=1 \%$

\section{KESIMPULAN}

Metode uji pemunculan radikula (RE) pada sepuluh varietas benih kedelai dengan tingkat vigor berbeda yang dikecambahkan selama 42 jam \pm 15 menit pada suhu $25 \pm 2$ ${ }^{\circ} \mathrm{C}$ berkorelasi erat dengan daya berkecambah, indeks vigor, kecepatan tumbuh, mean germination time, daya tumbuh, dan mean emergence time. Hasil verifikasi menunjukkan bahwa nilai RE 42 jam setelah pengecambahan dapat menduga daya berkecambah $(y=0.3293 x+59.591)$, MGT $(y=-0.1217 x+$ $48.458)$, daya tumbuh $(\mathrm{y}=1.0113 \mathrm{x}-14.70)$, dan MET $(\mathrm{y}=$ $-0.0607 x+11.124)$. Apabila nilai $\mathrm{RE}=80 \%$, maka nilai $\mathrm{DB}$ $=85.9 \%$ dan DT $=66.2 \%$ dengan nilai koefisien korelasi 0.78 (DB) dan 0.85 (DT) serta koefisien determinasi 0.57 (DB) dan 0.72 (DT). Uji RE dapat digunakan sebagai uji cepat vigor benih kedelai. 


\section{DAFTAR PUSTAKA}

Demir, I., B.B. Kenanoglu, E. Özden. 2019. Seed vigour tests to estimate seedling emergence in cress (Lepidium sativum L.) seed lots. Not. Bot. Horti. Agrobo. 47:881-886.

Demir, I., S. Ermis, K. Mavi, S. Matthews. 2008. Mean germination time of pepper seed lots (Capsicum annuит L.) predicts size and uniformity of seedlings in germination tests and transplant modules. Seed Sci. Technol. 36:21-30.

Dina, E. Widajati, B. Wirawan, S. Ilyas. 2007. Pola topografi pewarnaan tetrazolium sebagai tolok ukur viabilitas dan vigor benih kedelai (Glycine max L. Merr.) untuk pendugaan pertumbuhan tanaman di lapangan. Bul. Agron. 35:88-95.

Ermis, S., M. Karslıoglu, E. Ozden, I. Demir. 2015. Use of a single radicle emergence count as a vigour test in prediction of seedling emergence potential of leek seed lots. Seed Sci. Technol. 43:308-312.

Finch-Savage, W.E., G.W. Bassel. 2016. Seed vigour and crop establishment: Extending performance beyond adaptation. J. Exp. Bot. 67:567-591.

Hipi, A., Fitratunnisa, Herawati, N. 2016. Kajian daya simpan benih beberapa varietas kedelai. hal. 769-775. Dalam Muslimin, E.S. Rohaeni, A. Noor, Suryana, R. Galib, N. Amali, A. Gazali, H. Susanti, L.N. Hasanah (Eds.). Prosiding Seminar Nasional Inovasi Teknologi Pertanian. Banjarbaru 20 Juli 2016.

[ISTA] International Rules for Seed Testing. 2017. International Seed Testing Association, Bassersdorf, Switzerland. SUI.

[Kepmentan] Keputusan Mentri Pertanian. 2018. Petunjuk Teknis Sertifikasi Benih Tanaman Pangan No. 991/ hk.150/c/05/2018. Jakarta. ID.

Khajeh-Hosseini, M., M. Nasehzadeh, S. Matthews. 2010. Rate of physiological germination relates to the percentage of normal seedlings in standard germination tests of naturally aged seed lots of oilseed rape. Seed Sci. Technol. 38:602-611.
Lv, Y.Y., Y.R. Wang, A.A. Powell. 2016. Frequent individual counts of radicle emergence and mean just germination time predict seed vigour of Avenasativa and Elymus nutans. Seed Sci. Technol. 44:189-198.

Matthews, S., A. Powell. 2011. Towards automated single counts of radicle emergence to predict seed and seddling vigour. Seed Testing Int. 142:44-48.

Matthews S., E. Beltrami, R. El-Khadem, M. K. Hosseini, M. Nasehzadeh, G. Urso. 2011. Evidence that time for repair during early germination leads to vigour differences in maize. Seed Sci. Technol. 39:501-509.

Matthews, S., M. Khajeh-Hosseini. 2006. Mean germination time as an indicator of emergence performance in soil of seed lots of maize (Zea mays). Seed Sci. Technol. $34: 339-347$

Matthews, S., M. Wagner, L. Kerr, A. A. Powell. 2018. Potential for early counts of radicle emergence and leakage of electrolytes as quick test to predict the percentage of normal seedlings. Seed Sci. Technol. 46:1-18.

Mavi, K., A.A. Powell, Matthews, S. 2016. Rate of radicle emergence and leakage of electrolytes provide quick predictions of percentage normal seedlings in standard germination tests of radish (Raphanus sativus). Seed Sci. Technol. 44:393-409.

Onwimol, D., W. Chanmprasert, P. Changsee, T. Rongsangchaichareon. 2016. Seed vigorclassification using analysis of mean radicle emergence time and single counts of radicle emergence in rice (Oryza sativa L.) and mung bean (Vigna radiata (L.) Wilczek). Agric. Nat. Res. 50:345-350.

Ozden, E., C. Ozdamar, I. Demir. 2018. Radicle emergence test estimates predictions of percentage normal seedlings in standard germination test of aubergine (Solanum melongena L.) seed lots. Not. Bot. Horti. Agrobo. 46:177-182.

Powell, A.A., K. Mavi. 2016. Application of the radicle emergence test to radish (Raphanus sativus) seed. ISTA News Bull. 151:42. 